УДК 553.983

\title{
ПРОГНОЗ ЛИТОЛОГИЧЕСКОГО СОСТАВА БАЖЕНОВСКОЙ СВИТЬ НА ОСНОВЕ КОМПЛЕКСНОЙ ИНТЕРПРЕТАЦИИ ГЕОЛОГИЧЕСКИХ И ГЕОФИЗИЧЕСКИХ МАТЕРИАЛОВ
}

\author{
Фомин Михаил Александрович1,2, \\ FominMA@ipgg.sbras.ru
}

\author{
Костырева Елена Анатольевна 1 , \\ KostyrevaEA@ipgg.sbras.ru
}

Рыжкова Светлана Владимировна ${ }^{1,2}$, RizhkovaSV@ipgg.sbras.ru

\section{Саитов Рашид Маратович 1 , SaitovRM@ipgg.sbras.ru}

Сотнич Инга Сергеевна ${ }^{1}$, SotnichIS@ipgg.sbras.ru

\author{
Эдер Вика Георгиевна ${ }^{1}$, \\ EderVG@ipgg.sbras.ru \\ 1 Институт нефтегазовой геологии и геофизики им. А.А. Трофимука СО РАН, \\ Россия, 630090, г. Новосибирск, пр. Академика Коптюга, 3. \\ 2 Новосибирский государственный университет, \\ Россия, 630090, г. Новосибирск, ул. Пирогова, 1.
}

В связи с истощением запасов нефти в традиционных гранулярных коллекторах в Западно-Сибирской нефтегазоносной провинции все большую значимость приобретает разработка и совершенствование технологических приемов, увеличивающих объемы добычи нефти из низкопроницаемых пород баженовской свиты. Перспективы несртеносности этих отложений в значительной степени зависят от их литологии. В этой связи разработка методического подхода расчета минеральнокомпонентного состава баженовской свиты в скважинах, не охарактеризованных керновым материалом, представляется актуальным исследованием.

Объектом исследования являются карбонатно-елинисто-кремнистые породы баженовской свиты, характеризующиеся большой неоднородностью минерально-компонентного состава по разрезу.

Цель: выявление и изучение взаимосвязей между литологическим составом пород и электрическими и радиоактивными свойствами баженовской свиты в центральной части Западно-Сибирского осадочного бассейна для разработки методики расчета содержания основных породообразующих компонентов в разрезе этой свиты.

Методы: выявление взаимосвязей между минерально-компонентным составом пород баженовской свиты и ее электрическими и радиоактивными свойствами; статистический анализ полученных связей; расчет на их основе литологического состава баженовских пород в базовой, а также в соседних скважинах.

Результаты. В статье изложены результаты комплексной литолого-геофизической интерпретации данных широкого комплекса электрического и радиоактивного каротажа и результатов аналитических исследований керна, на основе которых разработан и апробирован методический подход к расчету концентраций основных породообразующих компонентов баженовской свиты. Он основывается на выявленных взаимосвязях между минерально-компонентным составом пород и их фризическими свойствами. Показана удовлетворительная сходимость расчетных значений и данных по керну, построена объемная литологическая модель для одной из скважин Дружной площади. Обосновано использование полученных взаимосвязей для достоверного расчета литологического состава баженовской свиты в близко расположенных скважинах, не охарактеризованных керновым материалом. Показана невозможность использования предлагаемого методического подхода на расстоянии в несколько десятков км, а также в тонкослоистых разрезах.

\section{Ключевые слова:}

Баженовская свита, Западная Сибирь, керн, ГИС, литологический состав, методический подход.

\section{Введение}

В Российской Федерации на фоне падения добычи нефти из традиционных коллекторов увеличивается доля трудноизвлекаемых запасов (ТРИЗ). В ближайшие два-три десятилетия развитие российской нефтяной промышленности будет в значительной степени связано с разработкой и внедрением технологий добычи нефти из сложных геологических объек- тов. В зрелой Западно-Сибирской нефтегазоносной провинции основные перспективы прироста запасов нефти на средне- и долгосрочную перспективу связаны с уникальным геологическим объектом - баженовской свитой (БС).

С точки зрения литологии, условий накопления органического вещества (OB) в осадке и его последующего преобразования, структуры пустотного про- 
странства этих пород полных аналогов баженовской свиты в мире нет [1]. Наиболее сходной по литологическому составу является американская формация Green River, которая содержит крупнейшее месторождение горючих сланцев в мире. Она входит в состав геологического образования Green River раннесреднеэоценового возраста, которое представляет собой комплекс отложений озерных, озерно-речных, дельтовых осадков и занимает юго-запад штата Вайоминг, северо-запад Колорадо, северо-восток Юты. Под керогенсодержащей формацией подразумеваются породы центральной озерной «сланцевой» части образования Green River. Эти отложения представляют собой переслаивание карбонатов и глинистых карбонатов с высокоуглеродистыми породами $\left(\mathrm{C}_{\text {орг }}\right.$ изменяется от 0,5 до 8,1\%, в среднем $3,1 \%$ ) от бежевых до черных, тонкослоистых, содержащих кероген I типа [2]. Нужно отметить относительно небольшие глубины залегания формации и, как следствие, низкую зрелость и степень преобразованности органического вещества: процесс вызревания ОВ и дальнейшей генерации жидких УВ затронул не более чем 10 \% от общего объема ОВ в формации.

Формация Green River считается перспективной с точки зрения нефтеносности. Специалисты по всему миру занимаются изучением пустотного пространства этих отложений методами компьютерной томографии [3], измерением их пористости и проницаемости до и после пиролитических исследований [4], анализом физических свойств керогена, определением скоростей выхода и химического состава углеводородов в зависимости от температуры и скорости нагревания образцов в процессе пиролиза [5-8]; моделированием пространственного распределения керогена в породе [9]; разработкой кинетических моделей реакции на основе пиролитических исследований [10]; изучением характеристик высокомолекулярных соединений в керогене с использованием метода спектроскопии ядерного магнитного резонанса 「11].

Формация Bakken (поздний девон - ранний карбон) является самым известным источником сланцевой нефти. Она занимает около 520 тыс. км² территории США (штаты Монтана, Северная Дакота) и Канады (провинции Саскачеван и Манитоба), залегает на глубинах от 2,5 до 3,5 км, а мощность не превышает 40 м [2]. Bakken состоит из трех основных литостратиграфических единиц: нижней и верхней низкопроницаемых сланцевых частей с высоким содержанием органического вещества I-II типа (в среднем 11,3\%) и средней относительно проницаемой части, состоящей из переслаивания песчаников, доломитизированных песчаников, доломитов и алевролитов, а также редких глинистых прослоев общей мощностью 10-20 м. Резервуаром формации Bakken является её средняя часть. Высокое содержание в ней кремнезема и доломита [12] увеличивает хрупкость породы, что способствует образованию трещин, обеспечивающих фильтрацию флюида при разработке этих пород.

Формация Eagle Ford позднемелового возраста простирается вдоль западного побережья Мексиканского залива от Восточного Техаса до Мексики. Бога- тая органическим веществом нижняя часть формации образовалась в основном в теплый и влажный период, что, вероятно, связано с субгумидной региональной климатической фазой во время сеноман-туронского глобального потепления и в условиях аноксии [13]. Формации Eagle Ford погружается в сторону Мексиканского залива в южном направлении, достигая глубин более 4,3 км. По мере увеличения глубины залегания изменяется тип и фазовое состояние пластового флюида: газ, сжиженный природный газ, нефть [1].

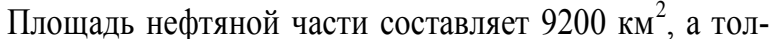
щина изменяется от 30 до 85 м (в среднем 76 м). Eagle Ford представляет собой сланец, в составе которого около 50-70 \% кальцита и доломита [14], остальное -

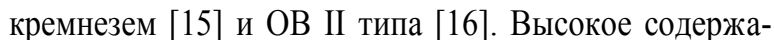
ние карбонатных минералов делает пласт хрупким и более подверженным трещинообразованию.

Геологическое образование Niobrara сланцевой нефти позднемелового возраста расположено в северо-восточной части штата Колорадо и захватывает части соседних Вайоминга, Небраски и Канзаса. Глубины залегания формации Niobrara увеличиваются от 1 км в восточной части до 3,5 км на западе, а толщина не превышает 100 м [1]. По аналогии с формацией Eagle Ford, по мере погружения изменяется зрелость органического вещества от верхней зоны газообразования до главной зоны нефтеобразования [17]. Изучая формацию Niobrara, исследователи установили переслаивание слоев почти чистого белого мела со слоями обломочных, богатых органикой, известковых глинистых сланцев. Общее содержание $\mathrm{C}_{\text {орг }}$, как правило, не превышает $6 \%$. Высокое содержание в породе мела обуславливает образование большого количества трещин [18], которые обеспечивают относительно высокие фильтрационно-емкостные свойства.

Таким образом, главным отличием баженовской свиты от американских нефтяных сланцевых аналогов является литологический состав. Она содержит большее количество глинистого и кремнистого вещества, ОВ как основного породообразующего компонента $[19,20]$ и меньшее количество карбонатного материала, представленного кальцитом и доломитом. Повышенное содержание глин и органического вещества уменьшает хрупкость баженовской свиты, что негативно влияет на образование и «продолжительность жизни» природных и искусственных трещин, которые обеспечивают повышенные фильтрационноемкостные свойства.

В настоящее время ведущие недропользователи страны проводят опытно-промышленную эксплуатацию баженовских отложений на своих лицензионных участках. Объем свободной нефти в этих низкопроницаемых породах в значительной степени определяется их литологией. В этой связи разработка методического подхода расчета минерально-компонентного состава баженовской свиты в скважинах, не охарактеризованных керновым материалом, представляется актуальным исследованием. В качестве объектов исследования выбраны разрезы баженовской свиты в северной части ХМАО (рис. 1). 
Важной особенностью баженовской свиты является неоднородность ее минерально-компонентного состава по разрезу и по площади. В изучаемом регионе разрезы, находящиеся друг от друга на расстоянии нескольких десятков километров, могут быть существенно различными [21-25], что обусловлено особенностями седиментации и постседиментационными преобразованями пород баженовских отложений. Для детального понимания геологии этой свиты и обоснования ее промышленной значимости в каждом конкретном районе необходимо изучать керн по густой сетке скважин (каждые 5-10 км), что попросту невозможно ввиду большой дороговизны и длительности аналитических исследований.

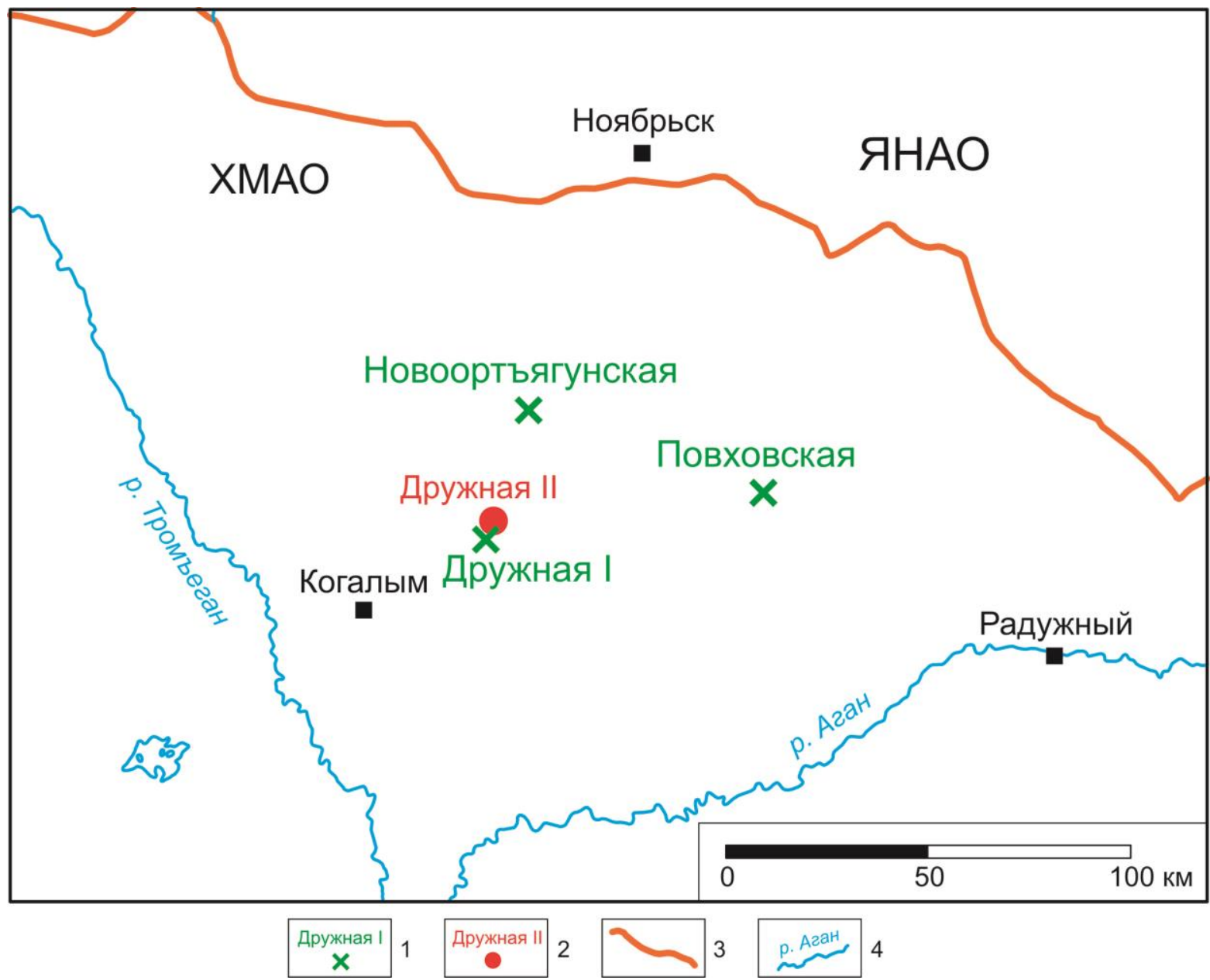

Рис. 1. Обзорная карта территории исследования: 1) скважины с результатами аналитических исследований кернового материала; 2) скважина, где была рассчитана литология по ГИС; 3) административная граница; 4) речная сеть

Fig. 1. Overview map of the study area: 1) wells with the results of analytical studies of core material; 2) well, where the lithology was calculated according to logging; 3) administrative boundary; 4) river network

Методы прогноза литологического состава нефтеперспективных, в том числе и черносланцевых, толщ активно применяются во всем мире [26, 27]. Предложена методика расчета литотипов (по данным ГИС) в разрезе баженовской свиты на Салымском месторождении [28]. На наш взгляд, такой подход вносит некоторый субъективизм в оценку литологии этой толщи, поскольку разными коллективами [19, 29-31] породы баженовской свиты классифицируются по-разному. Известны литологические модели, основанные на литолого-электрофизической интерпретации данных электромагнитных зондирований для определения вещественного состава баженовской свиты [32, 33], которые, однако, не учитывают альбит как один из основных минеральных компонентов.
Наиболее объективным нам кажется расчет на основе данных ГИС содержания основных породообразующих компонентов баженовской свиты. Наряду с кремнистым, глинистым, карбонатным материалом, альбитом и ОВ значимым минеральным компонентом является и образовавшийся в диагенезе пирит, содержание которого в баженовской свите, как правило, более $5 \%$, а в некоторых образцах в верхней части ее разреза на рассматриваемой территории превышает $10 \%$ [34].

В настоящей статье изложена методика расчета литологического состава баженовской свиты на основе данных электрического и радиоактивного каротажа. Представленный авторами подход основан на выявлении и обосновании физических связей между ми- 
нерально-компонентным составом пород и значениями указанных видов каротажа. Он позволяет прогнозировать литологический состав в разрезах, не охарактеризованных керновым материалом, расположенных в пределах одной или соседних площадей с разрезами, по которым проведены детальные литологические исследования. Для северных районов ХМАО такое исследование выполнено впервые.

Согласно последним дополнениям к [35] одним из признаков коллекторов I и II типов в баженовской свите является пониженное содержание глин, ОВ, пирита и повышенное содержание карбонатной и кремнистой составляющей, присутствие фосфатных разностей. Методика количественного прогноза литологического состава баженовской свиты, предложенная в этой статье, позволит выделять возможные интервалы-коллекторы в скважинах, не охарактеризованных керновым материалом.

\section{Фактический материал и методика исследования}

Для исследования использовались результаты определения литологического состава пород баженовской свиты (содержание глинистых и карбонатных минералов, кремнезема, альбита, пирита, апатита), полученные путем пересчета химического состава пород на минералогический по методике [36]. Для пересчета использовались результаты: 1) РФА о содержании породообразующих оксидов (ИГМ СО РАН); 2) химических методов анализа определения форм железа и серы (ИГМ СО РАН); 3) определения содержания органического углерода $\left(\mathrm{C}_{\text {орг }}\right)$ с помощью весового полумикрометода (ИНГГ СО РАН), полученные на экспресс-анализаторе (АН-7529) при температуре $1000-1100{ }^{\circ} \mathrm{C}$ в токе кислорода из нерастворимого остатка (НО) породы после ее обработки $10 \%$ соляной кислотой.

В скважине Дружная I, которая является базовой скважиной в настоящем исследовании, авторами выявлены физические связи между минеральнокомпонентным составом (карбонатный, глинистый и кремнистый материал, альбит, пирит, ОВ) баженовской свиты и данными электрического (БК - боковой каротаж, КС (зонд Gz3) - кажущееся удельное сопротивление; микрокаротаж: МГЗ - микроградиент зонд, МПЗ - микропотенциал зонд, МБК - микробоковой каротаж) и радиоактивного (ГК - гамма-каротаж, НГК - нейтронный гамма-каротаж, НКТБ и НКТМ нейтронный каротаж по тепловым нейтронам (большой и малый зонды), ГГК-П - гамма-гамма плотностной каротаж) каротажа. Для более точного выделения границ баженовской свиты кроме вышеперечисленных видов ГИС использовался также индукционный каротаж и каверномер. Для корректного выполнения исследования все значения ГИС были нормированы, т. е. пересчитаны в диапазоне от 0 до 1 по методике, приведенной в работе [29]. После этого в программном пакете GeoOffice Solver с помощью статистических графиков были проанализированы трехмерные зависимости содержания каждого породообразующего компонента от нескольких видов каротажа, которые послужили основой расчета их со- держания в породе. Расчетные кривые были сопоставлены с данными по керну. На основе связей керн-ГИС, установленных в базовой скважине, был рассчитан литологический состав баженовской свиты в скважине Дружная II, расположенной в 5 км от нее, а также в одной из скважин Повховской площади.

\section{Литологический состав баженовской свиты} и его отражение в физических полях

Ниже приводится краткое литологическое описание основных пачек баженовской свиты в одной из скважин Дружной площади (снизу вверх по разрезу) в соответствии с классификацией пород баженовской свиты, представленной в работе [19]. Выделяемые в разрезе баженовской свиты шесть пачек отличаются по соотношению содержаний углеродистой, глинистой, кремнистой и карбонатной компонент пород, что определяется обстановками их седиментации [20, 21]. Границы пачек были сначала определены по их литологическому составу, а затем были скорректированы по ГИС.

Пачка 1 (3,7 м) - представлена преимущественно силицитами, в кровле залегают силицитырадиоляриты, в некоторых разрезах карбонатизированные [24], вблизи подошвы в силицитах присутствуют зерна глауконита и единичные фосфатные линзы. На кривых ГИС пачка представлена более высокими относительно подстилающей георгиевской свиты значениями бокового каротажа. Отмечаются локальные увеличения естественной радиоактивности пород, связанные с повышенными концентрациями OB в породах. В целом значения ГК плавно возрастают снизу вверх по разрезу. Для этой пачки по сравнению с перекрывающими характерно увеличение значений НКТБ и НКТМ, а также плотностного каротажа - в прикровельной части наблюдается пик значений по ГГК-П, что может быть связано с мощным прослоем радиолярита. К сожалению, в этом интервале разреза образцы не были отобраны, однако южнее и западнее такой прослой по литологическим данным в разрезе баженовской свиты выделяется [20].

Пачка 2 (3,1 м) - силициты керогеновые (скрытокристаллические) с прослоями силицитов-радиоляритов; в нижней половине пачки распространены известковые прослои. В связи с увеличением концентраций ОВ до 8-10 \% в этой пачке отмечаются повышенные по сравнению с пачкой 1 значения гамма-каротажа и бокового каротажа. Многочисленные прослои радиоляритов отмечаются локальными максимумами на диаграммах ГГК-П и локальными минимумами на кривой ГК.

Пачка 3 (6,2 м) - силициты керогеновые (скрытокристаллические) с прослоями силицитоврадиоляритов, в некоторых разрезах карбонатизированных. На кривых ГИС для этой пачки характерны еще более высокие значения по ГК и БК, чем для пачки 2, что связано с увеличением содержания ОВ до $12-14 \%$. Редкие прослои с повышенным содержанием карбонатного материала отмечаются локальными пиками на кривых НКТМ и НКТБ. В прикровельной части выделяется плотный интервал, выражен- 
ный повышенными значениями на кривых плотностного и нейтронного каротажа.

Пачка 4 (2,7 м) - микститы кероген-кремнистые с прослоями силицита керогенового скрытокристаллического или силицита-радиолярита; в верхней части пачки присутствуют частые тонкие известковые прослои. На каротажных диаграммах эта высокоуглеродистая пачка отмечается ярко выраженным пиком естественной радиоактивности, пониженными по отношению в выше- и нижележащим отложениям значениями нейтронного и плотностного каротажа, высокими значениями БК.

Пачка 5 (4,5 м) - нижняя часть пачки слагается микститами кероген-кремнистыми вверх по разрезу, переходящими в тонкое переслаивание микститов кероген-глинисто-кремнистых и кероген-карбонатнокремнистых с остатками кокколитофоридовых водорослей, для пачки характерно присутствие частых известковых конкреций (0,5-3 см). Породы этой пачки на каротажных диаграммах характеризуются максимальными значениями электрического сопротивления В низах пачки выделяется ярко выраженные пики по ГК и БК, которые коррелируют с прослоями с наиболее высокими в этом разрезе содержаниями ОВ $23 \%$. В пачке установлены повышенные концентрации пирита, достигающие 15 \%. В верхней части пачки преобладает карбонатный материал, который отражается в физических полях повышенными значениями ГГК-П, НКТБ и НКТМ.

Пачка 6 (1,4 м) - микститы кремнисто-глинистые, пиритизированные, в некоторых разрезах с прослоями известняка или доломита. На диаграммах ГИС в средней части этой пачки отмечаются наибольшие во всем разрезе свиты значения ГК, обусловленные высокими содержаниями ОВ. Повышенное содержание пирита, определенное в одном из образцов, также связано с высокими значениями ОВ [34] и отмечается локальными пиками значений электрического сопротивления. В верхней части пачки наблюдается повышение значений ГГК-П, НКТБ и НКТМ, обусловленное постепенным сокращением в разрезе содержания $\mathrm{OB}$ и увеличением глинистой компоненты.

Перечисленные выше виды ГИС являются наиболее значимыми при характеристике литологического состава баженовской свиты. Эти методы использовались в дальнейшем для установления связей кернГИС и расчетов минерально-компонентного состава этих отложений.

\section{Результаты и их обсуждение}

Как известно, баженовская свита характеризуется пониженной относительно выше- и нижележащих отложений плотностью в связи с высоким содержанием в ней ОВ (керогена, согласно [19]) и пониженным содержанием глинистых минералов. Радиоактивность черносланцевых пород находится в тесной связи с содержанием в них ОВ [37, 38], которое является сорбентом урана из морской воды. Содержание ОВ в баженовской свите и перекрывающих отложениях, как было показано ранее [39-41], имеет устойчивую связь с радиоактивным каротажем: ГК (рис. 2, a), ГГК-П (рис. 2, б), НКТБ, а концентрации глинистых минералов в этом же интервале разреза лучше всего коррелируют с БК (рис. 3, a) и ГГК-П (рис. 3, б).
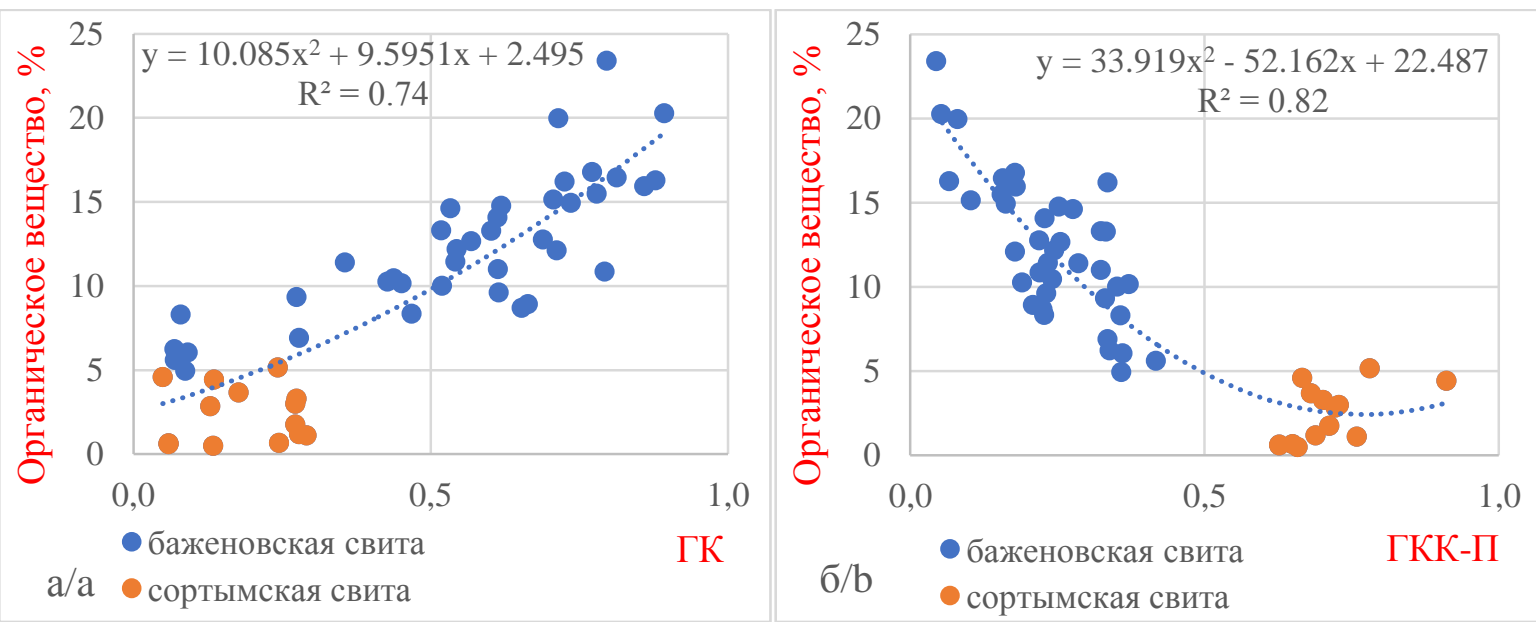

Рис. 2. Взаимосвязь содержания органического вешества и значений гамма-каротажа (а) и гамма-гамма плотностного (б) каротажа для баженовской свиты и нижней части сортымской свиты

Fig. 2. Relationship between organic matter content and values of gamma-ray logging (a) and gamma-gamma density (b) logging for the Bazhenov Formation and the lower part of the Megion Formation

Более темные (коричневые) точки на графиках относятся к переходной области от баженовской к сортымской свите - в этих образцах уже возрастает глинистость (до 55-60 \% против 20-25\% в баженовской свите), но еще достаточно высокое содержание ОВ
(3-5 \% против 0,5-1 \% в вышележащих слоях сортымской свиты). В рамках исследования баженовская свита и нижняя (переходная) часть сортымской свиты рассматриваются для установления связей керн-ГИС как единая непрерывная толща пород сходного генезиса. 

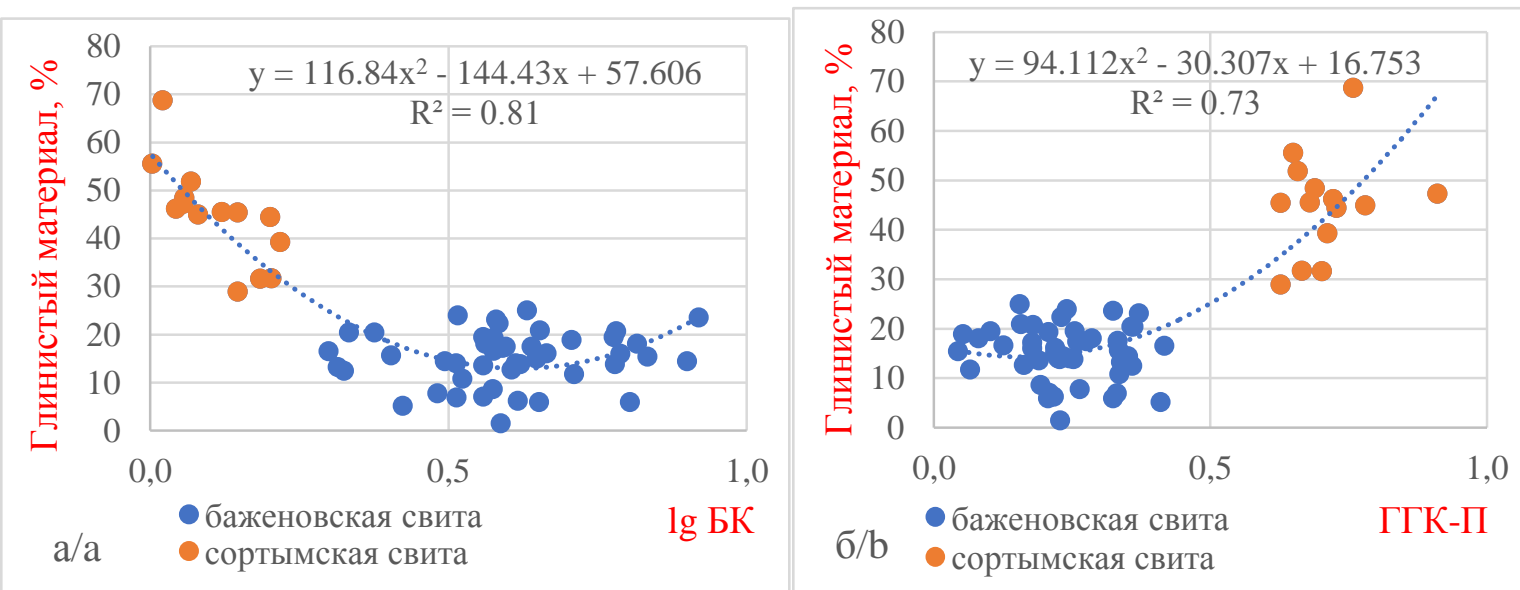

Рис. 3. Взаимосвязь содержания глинистых минералов и значений бокового (а) каротажа и значений гамма-гамма плотностного каротажа (б) для баженовской свиты и нижней части сортымской свиты

Fig. 3. Relationship between the content of clay minerals and the values of lateral (a) logging and values of gamma-gamma density logs (b) for the Bazhenov Formation and the lower part of the Megion Formation

В верхней приграничной части разреза баженовской свиты концентрация ОВ уменьшается, возрастает содержание пирита, что связано с миграцией сульфидсодержащих флюидов и сероводородсодержащих растворов из баженовской свиты в диа- и катагенезе $[21,34]$. Концентрации пирита находятся в тесной корреляции с удельным электрическим сопротивлением значениями бокового и микробокового каротажа. Такие устойчивые связи объясняются тем, что содержание пирита в большинстве случаев тесно связано с концентрациями ОВ (в том числе и жидких углеводородов) в баженовской свите, которые характеризуются высоким электрическим сопротивлением. Содержания кремнистого материала и альбита (рис. 4) имеют хорошо выраженные связи с удельным электрическим сопротивлением пород (БК, МБК), а также с ГГК-П. Концентрации карбонатного материала коррелируют со значениями всех рассмотренных видов нейтронного каротажа и удельным электрическим сопротивлением.

Полученные расчетные кривые хорошо увязываются с данными по керну, что подтверждается высокими значениями величины достоверной аппроксимации $\left(\mathrm{R}^{2}\right)$, которая для разных компонентов изменяется от 0,7 до 0,9. Представленная на планшете (рис. 5) объемная модель наглядно показывает относительное содержание основных породообразующих компонентов в баженовской свите и их распределение по разрезу.

На основе установленных взаимосвязей керн-ГИС было рассчитано содержание основных компонентов в скважине Дружная II (рис. 6), которая находится на расстоянии около 5 км от скважины Дружная I. Близкое расположение скважин и сходные диапазоны значений всех видов ГИС позволяют предполагать схожий литологический состав баженовской свиты, поэтому полученные расчетные данные можно считать достоверными. В этой скважине хорошо прослеживаются границы всех шести пачек, выделенных в базовой скважине. Важно отметить, что сумма полученных расчетных значений содержания породных компонентов в скважине Дружная II составила около 100 \% в каждой рассчетной точке разреза.
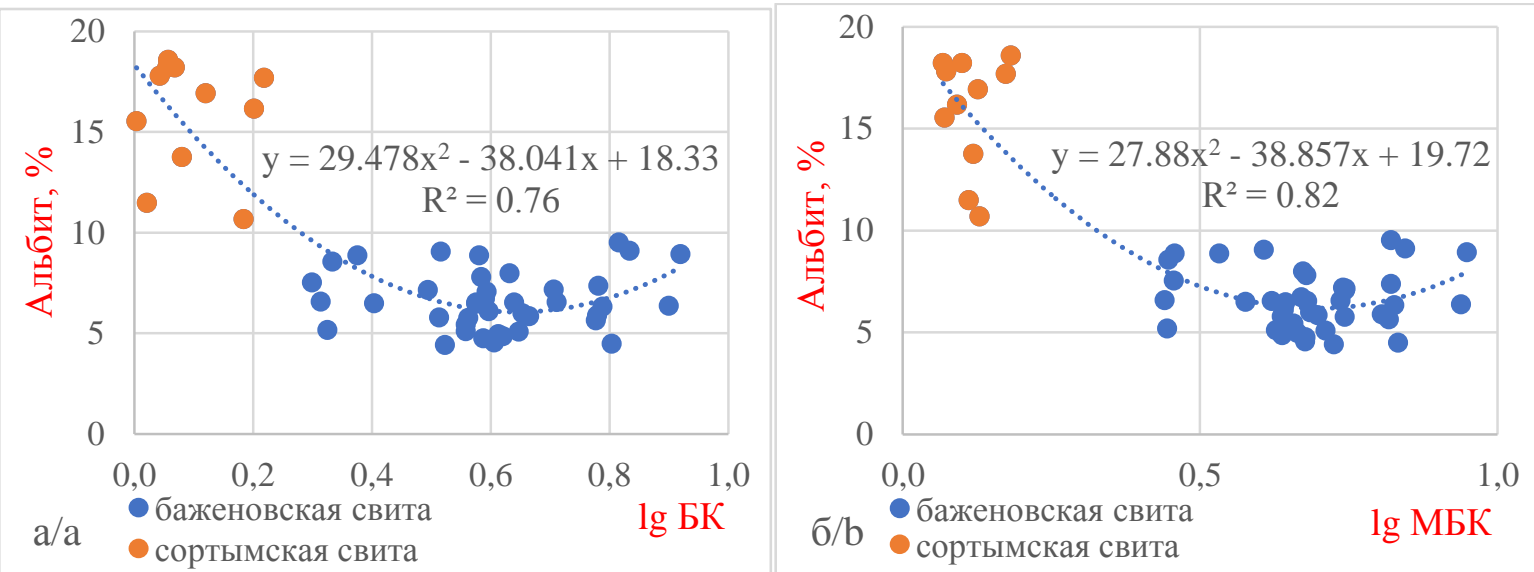

Pис. 4. Взаимосвязь содержания альбита и значений бокового (а) и микробокового (б) каротажа для баженовской свиты и нижней части сортымской свиты

Fig. 4. Relationship between albite content and lateral (a) and micro-lateral (b) logging values for the Bazhenov Formation and the lower part of the Megion Formation 


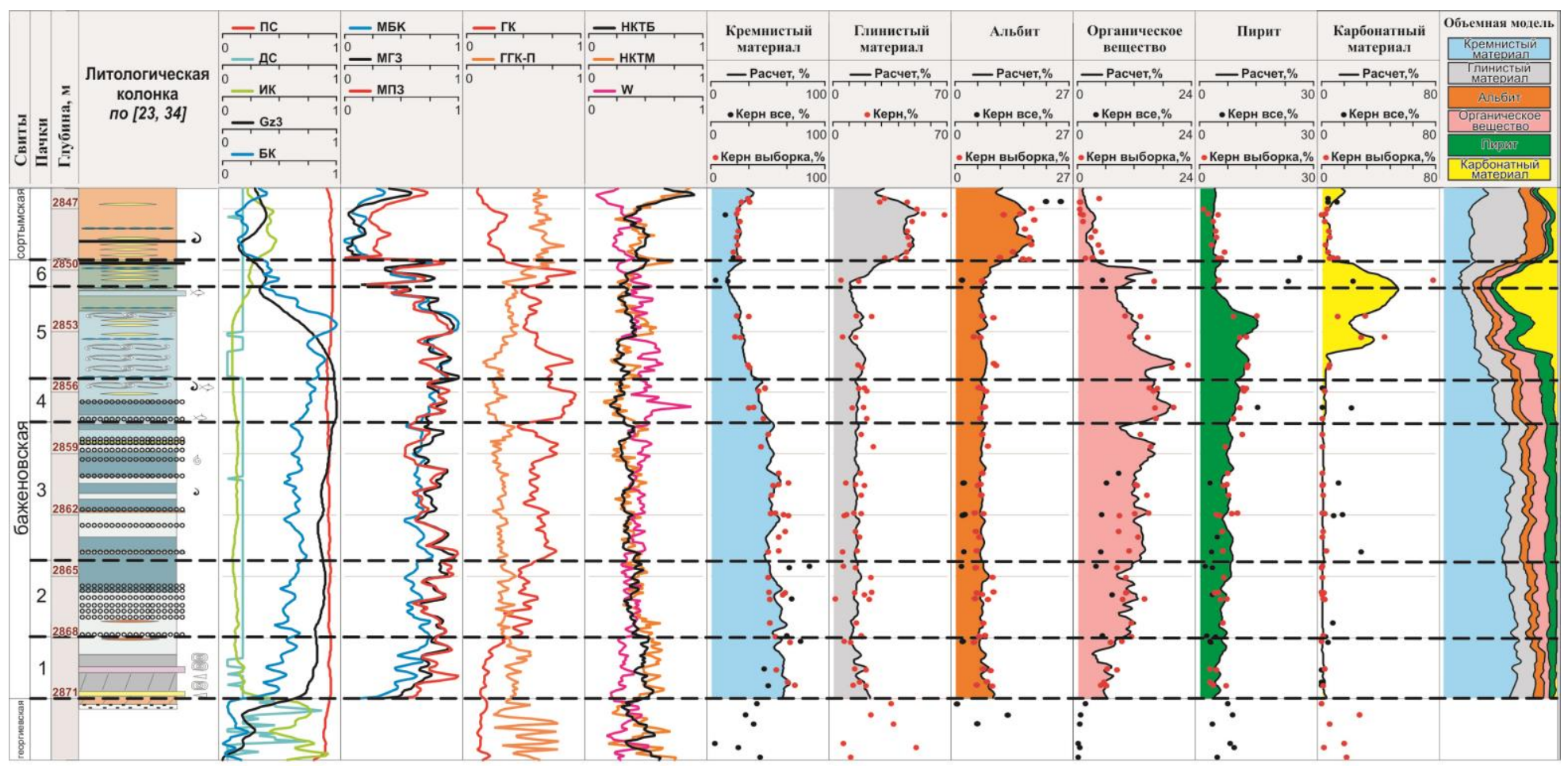

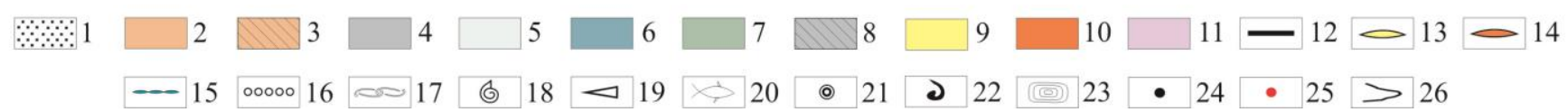

Рис. 5. Геолого-геофизический планшет по скважине Дружная I. Типы пород: 1 - песчаник, 2 - аргиллит, 3 - микстит кремнистый, 4 - микстит глинисто-кремнистый, 5 - силииит, 6 - силицит керогеновый, 7 - микстит кероген-кремнистый, кероген-кремнисто-карбонатный, 8 - микстит глинистый, 9 - известняк, 10 - порода с содержанием апатита $>5 \%, 11$ - порода с содержанием родохрозита $>25 \%$ : Аутигенные минералы: 12 - прослои пирита, 13 - известковая линза, 14 - линзы с содержсанием апатиma $>5 \%, 15$ - линзы микрокристаллического кремнезема; Органические остатки: 16 - прослои радиолярита, 17 - прослои с двустворками, 18 - аммониты, 19 - белемниты, 20 - остатки рыб, 21 - кокколитофориды, 22 - крючки онихитес, 23 - онколиты, 24 - все определения минерального состава пород по керну, 25 - определения минерального состава пород по керну, используемые для установления связей керн-ГИС, 26-расчетные кривые минерального состава пород

Fig. 5. Geological and geophysical chart of one of the Druzhnaya I well. Rock types: 1 - sandstone, 2 - mudstone, 3 - siliceous mixtite, 4 - argillaceous-siliceous mixtite, 5 - silicite, 6 - kerogen silicite, 7 - kerogen-siliceous mixtite, kerogen-siliceous-carbonate, 8 -argillaceous mixtite, 9 - limestone, 10 - rock with apatite content $>5 \%$, 11 - rock with rhodochrosite content $>25 \%$; Authigenic minerals: 12 - pyrite interlayers, 13 - lime lens, 14 - lenses with apatite content $>5 \%$, 15 - microcrystalline silica lenses; Organic remains: 16 - radiolarite interlayers, 17 - interlayers with bivalves, 18 - ammonites, 19 - belemnites, 20 - fish remains, 21 - coccolithophorids, 22 - onychites hooks, 23 - oncoliths, 24 - all determinations of the mineral composition of rocks by core, 25 - determination of the mineral composition of rocks from the core, used to establish the core-GIS relation, 26 - calculated curves of the mineral composition of rocks 


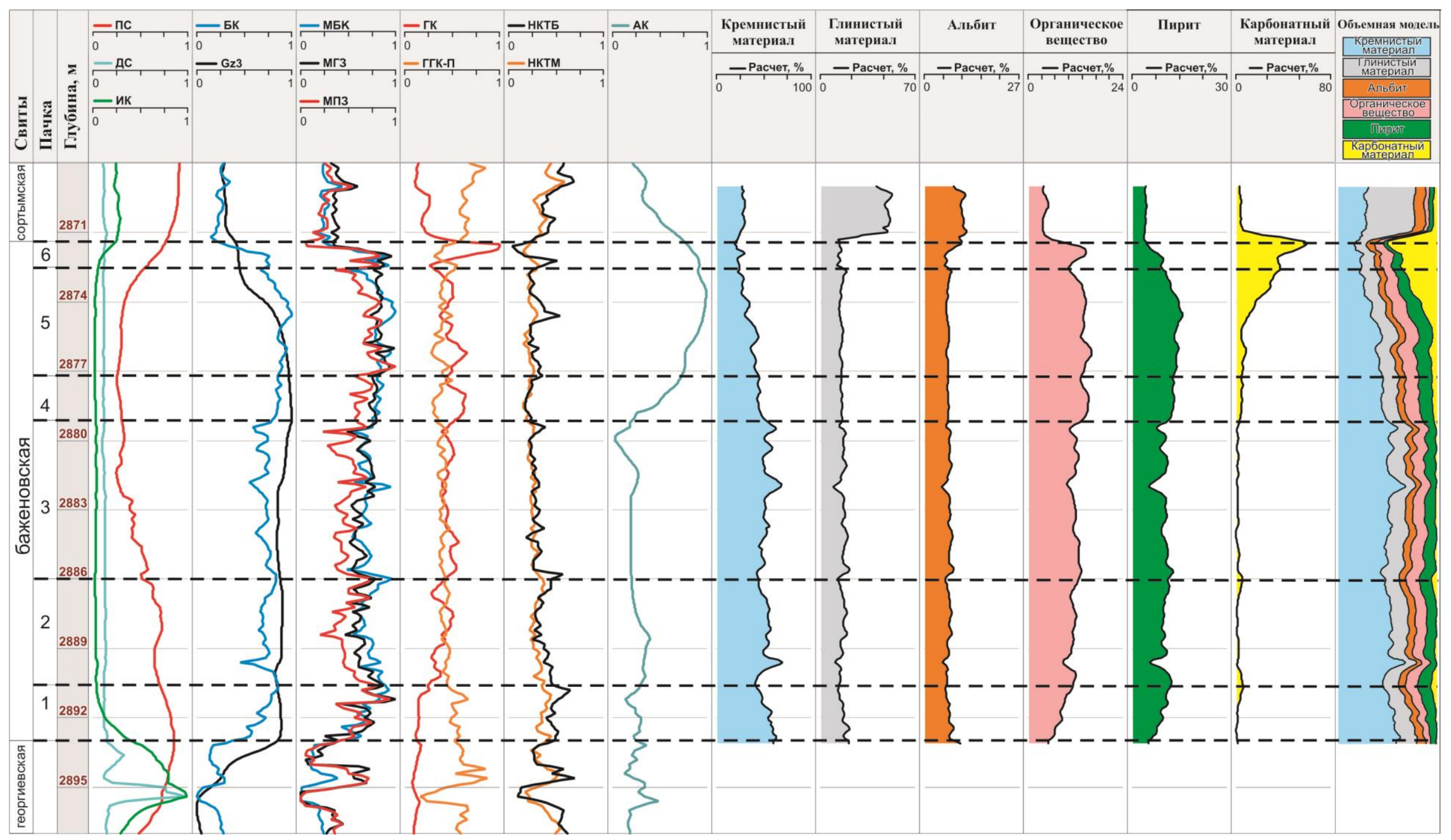

Pис. 6. Геолого-геофизический планшет по скважине Дружная II (условные обозначения - на рис. 5)

Fig. 6. Geological and geophysical chart of one of the Druzhnaya II well (see Fig. 5 for legend) 


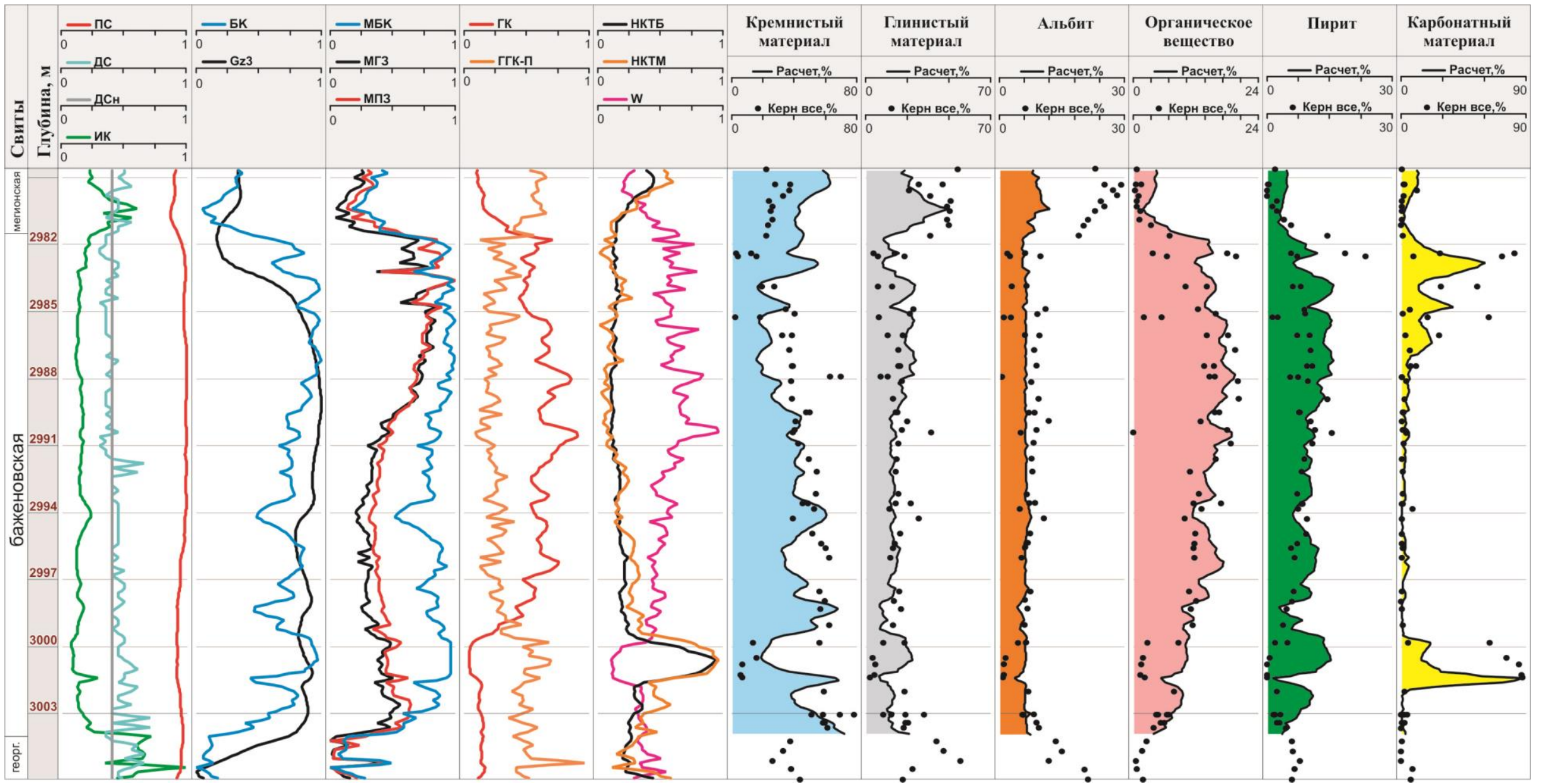

Pис. 7. Геолого-геофизический планшет по скважине Повховская (условные обозначения - на рис. 5)

Fig. 7. Geological and geophysical chart of one of the Povhovskaya well (see Fig. 5 for legend) 
Используя зависимости керн-ГИС, полученные в скважине Дружная I, был рассчитан литологический состав баженовской свиты в скважине Повховская (рис. 7), расположенной в 40 км от базовой скважины. В отличие от Дружной площади, разрез баженовской свиты в Повховской площади менее однороден, особенно в его верхней части. Было установлено, что расчетные кривые содержания кремнистого материала и пирита неудовлетворительно сопоставляются с данными по керну. Расчетные содержания органического вещества, глинистого материала и пирита значительно хуже, чем в Дружной I, коррелируют с фактическими данными. Из этого сделан вывод о невозможности корректного использования выявленных связей керн-ГИС на таких расстояниях от базовой скважины.

Также предлагаемая методика расчета не применима в сильно слоистых разрезах, когда образцы, отобранные на расстоянии 5-7 см друг от друга, имеют значимо разный минеральный состав и, следовательно, контрастные свойства. Например, верхняя часть разреза на Новоортьягунской площади представлена переслаиванием микститов кероген-глинисто-кремнистых и керогенкремнисто-карбонатных с реликтами кокколит. Толщина этих прослоев составляет 3-5 см [24], что намного меньше разрешающей способности приборов ГИС, не превышающей 30-40 см. В таких тонкослоистых разрезах породы с существенно разной литологией будут иметь одинаковые значения физических параметров, что не позволяет установить связи керн-ГИС.

\section{Выводы}

На основе комплексного анализа данных различных видов электрического и радиоактивного каротажа и результатов аналитических исследований керна выработан методический подход для расчета концен-

\section{СПИСОК ЛИТЕРАТУРЫ}

1. Soeder D.J., Borglum S.J. The fossil fuel revolution: shale gas and tight oil. - Eastbourne: Elsevier, 2019. - 336 p.

2. Нефть и газ низкопроницаемых сланцевых толщ - резерв сырьевой базы углеводородов России / О.М. Прищепа, О.Ю. Аверьянова, А.А. Ильинский, Д. Морариу. - СПб: Изд-во ФГУП «ВНИГРИ», 2014. - 323 с.

3. Microstructural imaging and characterization of oil shale before and after pyrolysis / T. Saif, Q. Lin, B. Bijeljic, M.J. Blunt // Fuel. - 2017. - V. 197. - P. 562-574.

4. 4D in situ synchrotron X-ray tomographic microscopy and laserbased heating study of oil shale pyrolysis / T. Saif, Q. Lin, Y. Gaoa, Y. Al-Khulaifia, F. Maroneb, D. Hollisc, M.J. Blunt, B. Bijeljic // Applied Energy. - 2019. - V. 235. - P. 1468-1475.

5. Primary understanding of non-isothermal pyrolysis behavior for oil shale kerogen using reactive molecular dynamics simulation / Y. Qian, J.-H. Zhan, D. Lai, M. Li, X. Liu, G. Xu // International journal of hydrogen energy. - 2016. - V. 41. - P. 12093-12100.

6. Burnham A.K. Porosity and permeability of Green River oil shale and their changes during retorting // Fuel. - 2017. - V. 203. - P. 208-213.

7. Kar T., Hascakir B. In-situ kerogen extraction via combustion and pyrolysis // Journal of Petroleum Science and Engineering. 2017. - V. 154. - P. 502-512.

8. Modeling study on effects of intraparticle mass transfer and secondary reactions on oil shale pyrolysis / Y. Huang, M. Zhang, J. Lyu, H. Yang, Q. Liu // Fuel. - 2018. - V. 221. - P. 240-248.

9. Quantification of organic content in shales via near-infrared imaging: Green River Formation / Y. Mehmani, A.K. Burnham, M.D.V. Berg, H.A. Tchelepi // Fuel. - 2017. - V. 208. - P. 337-352 траций основных породообразующих компонентов баженовской свиты, построена объемная модель их содержания в разрезе одной из скважин Дружной площади. Показано, что полученные зависимости можно использовать для достоверного расчета литологического состава баженовской свиты в близко расположенных скважинах.

Применение предложенного методического подхода будет способствовать:

1) более корректному сопоставлению разрезов без керна, включая прослеживание пачек, отвечающих определенным этапам осадконакопления баженовской свиты;

2) уточнению закономерностей распространения основных компонентов пород (кремнезем, глинистый материал, карбонаты, альбит, пирит, ОВ) по отдельной площади, а при наращивании базы данных - в целом для верхнеюрско-нижнемелового Западно-Сибирского палеобассейна, что, в свою очередь, будет крайне важным для детальных палеогеографических реконструкций.

Результаты подобной литолого-геофизической интерпретации послужат основой для выделения интервалов-коллекторов в разрезе баженовской свиты, в том числе в скважинах, не охарактеризованных керновым материалом.

Установление и обоснование физических связей между минерально-компонентным составом баженовской свиты и значениями электрического и радиоактивного каротажа выполнено при финансовой поддержке РФФИ в рамках научного проекта № 20-35-90049 Аспиранты. Апробаиия методического подхода для расчета кончентрачий основных породообразующих компонентов баженовской свиты на основе выявленных связей керн-ГИС реализована при финансовой поддержке проекта НИР FWZZ-20220012 программы ФНИ

10. Tiwari P., Deo M. Compositional and kinetic analysis of oil shale pyrolysis using TGA-MS // Fuel. - 2012. - V. 94. - P. 333-341.

11. Salmon E., Behar F., Hatcher P.G. Molecular characterization of Type I kerogen from the Green River Formation using advanced NMR techniques in combination with electrospray ionization/ultrahigh resolution mass spectrometry // Organic Geochemistry. - 2011. - V. 42. - P. 301-315.

12. Milliken K.L., Zhang T., Ni J.Y. Chen Mineral diagenetic control of expulsion efficiency in organic-rich mudrocks, Bakken Formation (Devonian-Mississippian), Williston Basin, North Dakota, U.S.A. // Marine and Petroleum Geology. - 2021. - V. 127. - P. 1-24.

13. Paleoenvironment and source-rock potential of the CenomanianTuronian Eagle Ford Formation in the Sabinas basin, northeast Mexico / J.J. Enciso-Cardenas, F. Núnez-Useche, L.F.C. Ortegon, G. de la Rosa-Rodríguez, M. Martínez-Yanez, A.G. Borrego // Journal of South American Earth Sciences. - 2021. - V. 108. - P. 1-14

14. Jiang S., Mokhtari M. Characterization of marl and interbedded limestone layers in the Eagle Ford Formation, DeWitt county, Texas // Journal of Petroleum Science and Engineering. - 2019. V. 172. - P. 502-510.

15. Milliken K.L., Ergenea S.M., Ozkan A. Quartz types, authigenic and detrital, in the Upper Cretaceous Eagle Ford Formation, South Texas, USA // Sedimentary Geology. - 2016. - V. 339. - P. 273-288.

16. Geochemical evidence of organic matter source input and depositional environments in the lower and upper Eagle Ford Formation, south Texas / X. Sun, T. Zhang, Y. Sun, K.L. Milliken, D. Sun // Organic Geochemistry. - 2016. - V. 98. - P. 66-81.

17. Gentzis T. Review of the hydrocarbon potential of the Steele Shale and Niobrara Formation in Wyoming, USA: A major 
unconventional resource play? // International Journal of Coal Geology. - 2016. - V. 166. - P. 118-127.

18. Compositional fractionation of petroleum from reservoir to wellhead in the Niobrara shale oil play / Y. Han, B. Horsfield, N. Mahlstedt, H. LaReau, D.J. Curry // International Journal of Coal Geology. - 2018. - V. 198. - P. 156-166.

19. Классификация пород баженовской свиты / А.Э. Конторович, П.А. Ян, А.Г. Замирайлова, Е.А. Костырева, В.Г. Эдер // Геология и геофизика. - 2016. - Т. 57. - № 11. - С. 2034-2043.

20. Стратификация и детальная корреляция баженовского горизонта в центральной части Западной Сибири по данным литологопалеонтологического изучения керна и ГИС / И.В. Панченко, В.Д. Немова, М.Е. Смирнова, М.В. Ильина, Е.Ю. Барабошкин, В.С. Ильин // Геология нефти и газа. - 2016. - № 6. - С. 22-34.

21. Литолого-геохимические свидетельства катагенетических преобразований черных сланцев на примере баженовской свиты Западной Сибири / В.Г. Эдер, Н.С. Балушкина, А.Г. Замирайлова, А.Н. Фомин // Вестник Московского университета. Серия 4: Геология. - 2021. - № 1. - С. 58-70.

22. Основные типы разрезов нефтеносной баженовской свиты на северо-востоке Сургутского свода / Н.И. Коробова, О.М. Макарова, Г.А. Калмыков, Н.Н. Петракова, А.Ю. Юрченко, В.Ф. Шарафутдинов, С.Р. Корост, В.В. Калабин // Вестник Московского университета. Серия 4: Геология. - 2015. - № 5. - С. 54-61.

23. Эдер В.Г., Замирайлова А.Г., Жигульский И.А. Литология баженовской свиты в районах Хантейской гемиантеклизы и Межовского мегамыса Западно-Сибирского нефтегазоносного бассейна // Геология нефти и газа. - 2016. - № 6. - С. 87-96.

24. Новые данные о литологии, органической геохимии и условиях формирования баженовской свиты Западной Сибири В.Г. Эдер, Е.А. Костырева, А.Ю. Юрченко, Н.С. Балушкина, И.С. Сотнич, Е.В. Козлова, А.Г. Замирайлова, Н.И. Савченко // Георесурсы. - 2019. - Т. 21. - № 2. - С. 129-142.

25. Модели седиментации баженовской свысокоуглеродистой формации в зоне развития тутлеймской и баженовской свит / О.В. Хотылев, Ю.А. Гатовский, Н.С. Балушкина, Ю.А. Коточкова, Н.И. Коробова, М.А. Фомина, Е.В. Карпова, Г.А. Калмыков // Георесурсы. - 2021. - Т. 23. - № 2. - С. 120-131.

26. Identifying organic-rich Marcellus Shale lithofacies by support vector machine classifier in the Appalachian basin / G. Wang, T.R. Carr, Y. Ju, C. Li // Computers and Geosciences. - 2014. V. 64. - P. 52-60.

27. Evaluation of machine learning methods for lithology classification using geophysical data / T.S. Bressan, M.K. Souza, T.J. Girelli, F.J. Chemale // Computers and Geosciences. - 2020. V. 139. - P. 1-13

28. Павлова М.А., Эдер В.Г., Замирайлова А.Г. Модель баженовской свиты на примере данных участка Салымского месторождения // Геология нефти и газа. - 2015. - № 3. - С. 57-62.

29. Калмыков Г.А., Балушкина Н.С. Модель нефтенасыщенности порового пространства пород баженовской свиты Западной Сибири и ее использование для оценки ресурсного потенциала. - М.: ГЕОС, 2017. - 246 с.
30. Основные типы пород баженовской свиты на Сургутском своде и сопредельных территориях / О.М. Макарова, Н.И. Коробова, А.Г. Калмыков, Г.А. Калмыков, Н.С. Балушкина, В.С. Белохин, Е.В. Козлова, В.Л. Косоруков, Е.А. Мануилова // Георесурсы. - 2017. - Спецвыпуск. - Ч. 2. - С. 155-164.

31. Немова В.Д. Многоуровневая литологическая типизация пород баженовской свиты // Нефтяное хозяйство. - 2019. № 8. - С. 13-17.

32. Глинских В.Н., Федосеев А.А. Новый подход к литологоэлектрофизической интерпретации данных электромагнитных зондирований в интервалах баженовской свиты // Геология и минерально-сырьевые ресурсы Сибири. - 2019. - № 4. C. $80-88$.

33. Частотная дисперсия электрофизических характеристик и электрическая анизотропия пород баженовской свиты по данным электрокаротажа / М.И. Эпов, В.Н. Глинских, А.М. Петров, К.В. Сухорукова, А.А. Федосеев, О.В. Нечаев, М.Н. Никитенко // Нефтяное хозяйство. - 2019. - № 9. - С. 62-64.

34. Эдер В.Г. Пиритизация пород зон перехода черносланцевой толщи к вмещающим отложениям на примере баженовской свиты Западной Сибири // Литология и полезные ископаемые. - 2020. - № 3. - С. 257-271.

35. Временное методическое руководство по подсчету запасов нефти в трещинных и трещинно-поровых коллекторах в отложениях баженовской толщи Западно-Сибирской нефтегазовой провинции // Недропользование XXI век. - 2017. - № 4. C. $68-101$.

36. Программа MINLITH для расчета минерального состава осадочных пород: достоверность результатов в применении к отложениям древних платформ / О.М. Розен, А.А. Аббясов, А.А. Мигдисов, А.А. Ярошевский // Геохимия. - 2000. - № 4. - С. 431-444.

37. Неручев С.Г. Эпохи радиоактивности в истории Земли и развитие биосферы // Геология и геофизика. - 1976. - № 5. - С. 3-13.

38. Неручев С.Г. Взаимосвязь эпох накопления органического вещества и урана с рубежами развития органического мира // Геохимия современных ископаемых осадков: VIII Международный конгресс по органической геохимии. - М.: Изд-во «Наука» 1982. - С. 5-15.

39. Плуман И.И. Ураноносность черных битуминозных аргиллитов верхней юры Западно-Сибирской плиты // Геохимия. 1971. - № 11. - С. 1362-1368.

40. Хабаров В.В., Нелепченко О.М., Первухина Т.М. Выделение проницаемых интервалов в породах баженовской свиты Салымского нефтяного месторождения // Геология нефти и га3а. - 1978. - № 8. - C. $15-18$.

41. Парфенова Т.М., Меленевский В.Н., Москвин В.И. Использование гамма-каротажа для определения содержания органического вещества в высокоуглеродистых осадочных формациях (на примере баженовской свиты) // Нефтяная и газовая промыщленность. Геология, геофизика и разработка нефтяных месторождений. - 1999. - № 11. - С. 29-34.

Поступила: 03.09.2021 г.

\section{Информация об авторах}

Фомин М.A., кандидат геолого-минералогических наук, заведующий лабораторией, Институт нефтегазовой геологии и геофизики им. А.А. Трофимука СО РАН; старший преподаватель кафедры геологии месторождений нефти и газа Геолого-геофизического факультета, Новосибирский государственный университет.

Kостырева E.A., кандидат геолого-минералогических наук, старший научный сотрудник, Институт нефтегазовой геологии и геофизики им. А.А. Трофимука СО РАН.

Pbжкова $\boldsymbol{C . B . , ~ к а н д и д а т ~ г е о л о г о - м и н е р а л о г и ч е с к и х ~ н а у к , ~ с т а р ш и и ̆ ~ н а у ч н ы и ̆ ~ с о т р у д н и к , ~ И н с т и т у т ~ н е ф т е г а з о - ~}$ вой геологии и геофизики им. А.А. Трофимука СО РАН; доцент кафедры геологии месторождений нефти и газа Геолого-геофизического факультета, Новосибирский государственный университет.

Caumoв P.M., младший научный сотрудник, Институт нефтегазовой геологии и геофизики им. А.А. Трофимука СО РАН.

Сотнич И.С., научный сотрудник, Институт нефтегазовой геологии и геофизики им. А.А. Трофимука СО РАН. Эдер В.Г., кандидат геолого-минералогических наук, старший научный сотрудник, Институт нефтегазовой геологии и геофизики им. А.А. Трофимука СО РАН. 
UDC 553.983

\title{
LITHOLOGICAL MODEL OF THE BAZHENOV FORMATION BASED ON INTEGRATED INTERPRETATION OF GEOLOGICAL AND GEOPHYSICAL MATERIALS
}

\author{
Mikhail A. Fomin ${ }^{1,2}$, \\ FominMA@ipgg.sbras.ru
}

Elena A. Kostyreva ${ }^{1}$, KostyrevaEA@ipgg.sbras.ru

Svetlana V. Ryzhkova ${ }^{1,2}$, RizhkovaSV@ipgg.sbras.ru

\section{Rashid M. Saitov ${ }^{1}$,} SaitovRM@ipgg.sbras.ru

Inga S. Sotnich ${ }^{1}$, SotnichIS@ipgg.sbras.ru

\section{Vika G. Eder ${ }^{1}$,} EderVG@ipgg.sbras.ru

1 Trofimuk Institute of Petroleum Geology and Geophysics SB RAS,

3, Ak. Koptyug avenue, Novosibirsk, 630090, Russia.

2 Novosibirsk State University,

1, Pirogov street, Novosibirsk, 630090, Russia.

The relevance of the study is associated with the need to develop and improve technological methods for increasing oil production from the Bazhenov Formation in relation to the depletion of reserves in traditional granular reservoirs in the West Siberian oil and gas province. The features of the industrial development of these low-permeability rocks largely depend on their mineral-component composition. To identify different types of reservoirs of the Bazhenov Formation in wells that are not characterized by core material, it is necessary to develop a method for predicting its lithological composition.

The main aim: to identify and study the relationships between the mineral component composition, and electrical rocks and radioactive properties of Bazhenov Formation in the central part of the West Siberian sedimentary basin for developing methods of calculating the content of basic rock-forming components in this formation section.

The object of the research is the carbonate-argillaceous-siliceous rocks of the Bazhenov Formation, characterized by a large heterogeneity of the mineral-component composition along the section.

Methods: identification of relationships between the mineral-component composition of the rocks of the Bazhenov Formation and its electrical and radioactive properties; statistical analysis of the obtained relations; calculation on their basis of the lithological composition of the Bazhenov rocks in the base, as well as in adjacent wells.

Results. The article presents the results of an integrated lithological and geophysical interpretation of data from a wide range of electrical and radioactive logging and the results of analytical core studies, on the basis of which a methodological approach to calculating the concentrations of the main rock-forming components of the Bazhenov Formation has been developed. It is based on the identified relationships between the mineral-component composition of rocks and their physical properties. Satisfactory convergence of the calculated values and core data is shown, volumetric lithological models are built for the wells of the Druzhnaya and Povkhovskaya areas. It is shown that the obtained dependences can be used to reliably calculate the lithological composition of the Bazhenov Formation in closely spaced wells that are not characterized by core material. The impossibility of using the proposed methodological approach in thin-layered sections is substantiated due to the fact that the thickness of the interlayers is much less than the resolving power of geophysical borehole probes.

Key words:

Bazhenov Formation, West Siberia, core, well-logging data, lithological composition, methodical approach.

Interconnection and substantiation of physical relationships between the mineral-component composition of the Bazhenov formation and the values of electrical and radioactive logging was funded by RFBR, project number 20-35-90049. Approbation of the methodological approach for calculating the concentrations of the main rock-forming components of the Bazhenov formation based on the identified core-logging relationships was implemented with the financial support of the research project FWZZ-2022-0012 of the FSI program.

\section{REFERENCES}

1. Soeder D.J., Borglum S.J. The fossil fuel revolution: shale gas and tight oil. Eastbourne, Elsevier, 2019. 336 p.

2. Prischepa O.M., Averyanova O.Yu., Ilyinsky A.A., Morariu D Neft i gaz nizkopronitsaemykh slancevykh tolshch - rezerv syrevoy bazy uglevodorodov Rossii [Oil and gas of low-permeable shale strata - a reserve of the raw hydrocarbon base of Russia]. St. Petersburg, FSUE «VNIGRI» Publ. house, 2014. 323 p.

3. Saif T., Lin Q., Bijeljic B., Blunt M.J. Microstructural imaging and characterization of oil shale before and after pyrolysis. Fuel, 2017, vol. 197, pp. 562-574. 
4. Saif T., Lin Q., Gaoa Y., Al-Khulaifia Y., Maroneb F., Hollisc D., Blunt M.J., Bijeljic B. 4D in situ synchrotron X-ray tomographic microscopy and laser-based heating study of oil shale pyrolysis. Applied Energy, 2019, vol. 235, pp. 1468-1475.

5. Qian Y., Zhan J.-H., Lai D., Li M., Liu X., Xu G. Primary understanding of non-isothermal pyrolysis behavior for oil shale kerogen using reactive molecular dynamics simulation. International journal of hydrogen energy, 2016, vol. 41, pp. 12093-12100.

6. Burnham A.K. Porosity and permeability of Green River oil shale and their changes during retorting. Fuel, 2017, vol. 203, pp. 208-213

7. Kar T., Hascakir B. In-situ kerogen extraction via combustion and pyrolysis. Journal of Petroleum Science and Engineering, 2017, vol. 154 , pp. 502-512.

8. Huang Y., Zhang M., Lyu J., Yang H., Liu Q. Modeling study on effects of intraparticle mass transfer and secondary reactions on oil shale pyrolysis. Fuel, 2018, vol. 221, pp. 240-248.

9. Mehmani Y., Burnham A.K., Berg M.D.V., Tchelepi H.A. Quantification of organic content in shales via near-infrared imaging: Green River Formation. Fuel, 2017, vol. 208, p. 337-352.

10. Tiwari P., Deo M. Compositional and kinetic analysis of oil shale pyrolysis using TGA-MS. Fuel, 2012, vol. 94, pp. 333-341.

11. Salmon E., Behar F., Hatcher P.G. Molecular characterization of Type I kerogen from the Green River Formation using advanced NMR techniques in combination with electrospray ionization/ultrahigh resolution mass spectrometry. Organic Geochemistry, 2011, vol. 42, pp. 301-315.

12. Milliken K.L., Zhang T., Chen J., Ni Y. Mineral diagenetic control of expulsion efficiency in organic-rich mudrocks, Bakken Formation (Devonian-Mississippian), Williston Basin, North Dakota, U.S.A. Marine and Petroleum Geology, 2021, vol. 127, pp. 1-24.

13. Enciso-Cardenas J.J., Núnez-Useche F., Ortegon L.F.C., de la RosaRodríguez G., Martínez-Yanez M., Borrego A.G. Paleoenvironment and source-rock potential of the Cenomanian-Turonian Eagle Ford Formation in the Sabinas basin, northeast Mexico. Journal of South American Earth Sciences, 2021, vol. 108, pp.1-14.

14. Jiang S., Mokhtari M. Characterization of marl and interbedded limestone layers in the Eagle Ford Formation, DeWitt county, Texas. Journal of Petroleum Science and Engineering, 2019, vol. 172 , pp. 502-510.

15. Milliken K.L., Ergenea S.M., Ozkan A. Quartz types, authigenic and detrital, in the Upper Cretaceous Eagle Ford Formation, South Texas, USA. Sedimentary Geology, 2016, vol. 339, pp. 273-288.

16. Sun X., Zhang T., Sun Y., Milliken K.L., Sun D. Geochemical evidence of organic matter source input and depositional environments in the lower and upper Eagle Ford Formation, south Texas. Organic Geochemistry, 2016, vol. 98, pp. 66-81.

17. Gentzis T. Review of the hydrocarbon potential of the Steele Shale and Niobrara Formation in Wyoming, USA: A major unconventional resource play? International Journal of Coal Geology, 2016, vol. 166, pp. 118-127.

18. Han Y., Horsfield B., Mahlstedt N., LaReau H., Curry D.J. Compositional fractionation of petroleum from reservoir to wellhead in the Niobrara shale oil play. International Journal of Coal Geology, 2018, vol. 198, pp. 156-166.

19. Kontorovich A.E., Yan P.A., Zamirailova A.G., Kostyreva E.A., Eder V.G. Classification of rocks of the Bazhenov Formation. Russian Geology and Geophysics, 2016, vol. 57, no. 11, pp. 1606-1612.

20. Panchenko I.V., Nemova V.D., Smirnova M.E., Ilyina M.V., Baraboshkin E.Yu., Ilyin V.S. Stratification and detailed correlation of the Bazhenov horizon in the central part of Western Siberia according to the lithological and paleontological study of core and GIS. Geology of oil and gas, 2016, no. 6, pp. 22-34. In Rus.

21. Eder V.G., Balushkina N.S., Zamirailova A.G., Fomin A.N. Lithological and geochemical evidence of catagenetic transformations in black shales based on the example of the Western Siberian Bazhenov Formation. Moscow University Geology Bulletin, 2021, vol. 76, pp. 163-175.

22. Korobova N.I., Makarova O.M., Kalmykov G.A., Petrakova N.N., Yurchenko A.Yu., Sharafutdinov V.F., Korost S.R., Kalabin V.V. The main types of sections of the oil-bearing Bazhenov formation in the north-east of the Surgut arch. Moscow University Geology Bulletin, 2015, vol. 70, no. 5, pp. 54-61.

23. Eder V.G., Zamirailova A.G., Zhigulsky I.A. Lithology of the Bazhenov Formation in the Khanteyskaya Hemianteclise and
Mezhovsky Megamys of the West Siberian Oil and Gas Basin. Geology of oil and gas, 2016, no. 6, pp. 87-96. In Rus.

24. Eder V.G., Kostyreva E.A., Yurchenko A.Yu., Balushkina N.S., Sotnich I.S., Kozlova E.V., Zamirailova A.G., Savchenko N.I. New data on lithology, organic geochemistry and conditions for the formation of the Bazhenov formation in Western Siberia. Georesources, 2019, vol. 21, no. 2, pp. 129-142. In Rus.

25. Khotylev O.V., Gatovsky Yu.A., Balushkina N.S., Kotochkova Yu.A., Korobova N.I., Fomina M.A., Karpova E.V., Kalmykov G.A. Models of sedimentation of the Bazhenov high-carbon formation in the development zone of the Tutleim and Bazhenov formations. Georesources, 2021, vol. 23, no. 2, pp. 120-131. In Rus.

26. Wang G., Carr T.R., Ju Y., Li C. Identifying organic-rich Marcellus Shale lithofacies by support vector machine classifier in the Appalachian basin. Computers and Geosciences, 2014, vol. 64, pp. $52-60$

27. Bressan T.S., Souza M.K., Girelli T.J., Chemale F.J. Evaluation of machine learning methods for lithology classification using geophysical data. Computers and Geosciences, 2020, vol. 139, pp. 1-13.

28. Pavlova M.A., Eder V.G., Zamirailova A.G. Model of the Bazhenov formation on the example of data from the Salym field. Geology of oil and gas, 2015, no. 3, pp. 57-62. In Rus.

29. Kalmykov G.A., Balushkina N.S. Model neftenasyshchennosti porovogo prostranstva porod bazhenovskoy svity Zapadnoy Sibiri $i$ ee ispolzovanie dlya otsenki resursnogo potentsiala [A model of oil saturation in the pore space of the rocks of the Bazhenov Formation in Western Siberia and its use for assessing the resource potential]. Moscow, GEOS Publ., 2017. 246 p.

30. Makarova O.M., Korobova N.I., Kalmykov A.G., Kalmykov G.A., Balushkin N.S., Belokhin V.S., Kozlova E.V., Kosorukov V.L., Manuilova E.A. The main types of rocks of the Bazhenov Formation in the Surgut arch and adjacent territories. Georesources, 2017, Special Iss., P. 2, pp. 155-164. In Rus.

31. Nemova V.D. Multilevel lithological typification of rocks of the Bazhenov Formation. Oil Industry, 2019, no. 8, pp. 13-17. In Rus.

32. Glinskikh V.N., Fedoseev A.A. A new approach to lithoelectrophysical interpretation of electromagnetic sounding data in the Bazhenovskaya Formation intervals. Geology and Mineral Resources of Siberia, 2019, no. 4, pp. 80-88. In Rus.

33. Epov M.I., Glinskikh V.N., Petrov A.M., Sukhorukova K.V., Fedoseev A.A., Nechaev O.V., Nikitenko M.N. Frequency dispersion of electrophysical characteristics and resistivity anisotropy of the Bazhenov formation deposits according to resistivity logging data. Oil Industry, 2019, no. 9, pp. 62-64. In Rus.

34. Eder V.G. Pyritization of rocks in black shale/host rock transition zones: evidence from the Bazhenov Formation, Western Siberia. Lithology and Mineral Resources, 2020, vol. 55, no. 3, pp. 218-230. In Rus.

35. Vremennoe metodicheskoe rukovodstvo po podschetu zapasov nefti $\mathrm{v}$ treshchinnykh $\mathrm{i}$ treshchinno-porovykh kollektorakh $\mathrm{v}$ otlozheniyakh bazhenovskoy tolshchi Zapadno-Sibirskoy neftegazovoy provintsii [Temporary guidelines for calculating oil reserves in fractured and fractured-porous reservoirs in the sediments of the Bazhenov strata of the West Siberian oil and gas province]. Subsoil use XXI century, 2017, no. 4, pp. 68-101.

36. Rosen O.M., Abbyasov A.A., Migdisov A.A., Yaroshevsky A.A. MINLITH program for calculating the mineral composition of sedimentary rocks: the reliability of the results as applied to the sediments of ancient platforms. Geochemistry, 2000, no. 4, pp. 431-444. In Rus.

37. Neruchev S.G. Epochs of radioactivity in the history of the Earth and the development of the biosphere. Russian Geology and Geophysics, 1976, no. 5, pp. 3-13. In Rus.

38. Neruchev S.G. Vzaimosvyaz epokh nakopleniya organicheskogo veshchestva i urana s rubezhami razvitiya organicheskogo mira [The relationship of the epochs of organic matter and uranium accumulation with the boundaries of development of the organic world]. VIII Mezhdunarodny kongress po organicheskoy geokhimii. Geokhimiya sovremennykh iskopaemykh osadkov [VIII International Congress on Organic Geochemistry. Geochemistry of modern fossil sediments]. Moscow, Nauka Publ., 1982. pp. 5-15.

39. Pluman I.I. Uranium content of black bituminous mudstones of the Upper Jurassic of the West Siberian plate. Geochemistry, 1971, no. 11, pp. 1362-1368. In Rus.

40. Khabarov V.V., Nelepchenko O.M., Pervukhina T.M. Allocation of permeable intervals in the rocks of the Bazhenov Formation of 
the Salym oil field. Geology of oil and gas, 1978, no. 8, pp. 15-18. In Rus.

41. Parfenova T.M., Melenevsky V.N., Moskvin V.I. The use of gamma-ray logging to determine the content of organic matter in high-carbon sedimentary formations (for example, the Bazhenov suite). Oil and Gas Industry. Geology, geophysics and oil field development, 1999, no. 11, pp. 29-34. In Rus.

Received: 3 September 2021.

\section{Information about the authors}

Mikhail A. Fomin, Cand. Sc., head of the laboratory, Trofimuk Institute of Petroleum Geology and Geophysics SB RAS; senior lecturer, Novosibirsk State University.

Elena A. Kostyreva, Cand. Sc., senior researcher, Trofimuk Institute of Petroleum Geology and Geophysics SB RAS.

Svetlana V. Ryzhkova, Cand. Sc., senior researcher, Trofimuk Institute of Petroleum Geology and Geophysics SB RAS; assistant professor, Novosibirsk State University.

Rashid M. Saitov, junior researcher, Trofimuk Institute of Petroleum Geology and Geophysics SB RAS.

Inga S. Sotnich, researcher, Trofimuk Institute of Petroleum Geology and Geophysics SB RAS.

Vika G. Eder, Cand. Sc., senior researcher, Trofimuk Institute of Petroleum Geology and Geophysics SB RAS. 